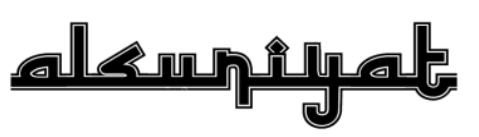

JURNAL PENELITIAN BAHASA, SASTRA, DAN

BUDAYA ARAB

P-ISSN: 2615-7241 | E-ISSN: 2721-480X // Vol. 1 No. 2 | 125-136

(1) https://ejournal.upi.edu/index.php/alsuniyat/index

\title{
ANALISIS BUKU AJAR BAHASA ARAB KELAS VI MADRASAH IBTIDAIAH TERBITAN KARYA TOHA PUTRA
}

\author{
Afifa Wijdan Azhari \\ Al Fursan Islamic School Bekasi, Indonesia \\ E-mail: afifawijdan@gmail.com
}

\begin{abstract}
:
Textbooks must meet the criteria for suitable textbooks that have been set by BSNP, and the teaching material in them is quality teaching material. The purpose of this study was to determine the Arabic language textbook class VI Issued by Toha Putra. whether the textbook meets BSNP standards and meets the quality of the textbook based on aspects of selection, gradation, presentation and repetition. The method used is documentation study and literature study. Based on the results of this study the book is a book that is not in accordance with BSNP standards and meets the quality of teaching materials based on aspects of selection, gradation, presentation, and repetition.

Keywords:

Textbooks; Quality; BSNP
\end{abstract}

\begin{abstract}
Abstrak
Buku ajar haruslah memenuhi kriteria buku ajar yang layak digunakan yang telah ditetapkan oleh BSNP, serta materi ajar di dalamnya merupakan materi ajar yang berkualitas. Tujuan penelitian ini adalah untuk mengetahui buku ajar bahasa Arab kelas VI Terbitan karya Toha Putra. apakah buku ajar tersebut sudah memenuhi standar BSNP dan telah memenuhi kualitas buku ajar berdasarkan aspek seleksi, gradasi, presentasi, dan repetisi. Metode yang digunakan adalah studi dokumentasi dan studi pustaka. Berdasarkan hasil penelitian ini buku adalah buku yang kurang sesuai dengan standar BSNP dan memenuhi kualitas materi ajar berdasarkan aspek seleksi, gradasi, presentasi, dan repetisi.

Kata Kunci:

Buku ajar; Kualitas; BSNP
\end{abstract}

\section{PENDAHULUAN}

Buku ajar termasuk komponen penting dalam pembelajaran. Buku ajar menjadi salah satu bahan pembelajaran yang utama. Sebagaimana disebutkan dalam Peraturan Menteri Pendidikan dan Kebudayaan Republik Indonesia Nomor 8 Tahun 2016 tentang buku yang digunakan dalam satuan pendidikan Pasal 1 yaitu: "Buku ajar pelajaran adalah sumber pembelajaran utama untuk mencapai kompetensi dasar dan kompetensi inti dan dinyatakan layak oleh kementerian Pendidikan dan Kebudayaan untuk digunakan pada satuan pendidikan."

Buku ajar memiliki ciri-ciri khusus apabila dibandingkan dengan jenis buku ilmiah lainnya. Ciri-ciri khusus buku ajar tersebut dipaparkan oleh Muslich (2010:61) sebagai berikut: 1) buku ajar disusun berdasarkan pesan kurikulum pendidikan, 2) buku ajar memfokuskan ke tujuan tertentu, 3) buku ajar menyajikan bidang pelajaran tertentu, 4) buku ajar berorientasi 
kepada kegiatan belajar siswa, 5) buku ajar dapat mengarahkan kegiatan belajar mengajar guru di kelas, 6) pola sajian buku ajar disesuaikan dengan perkembangan intelektual siswa sasaran.

Lebih lanjut, Sitepu (2015:21) menandaskan bahwa buku ajar berfungsi sebagai pedoman manual bagi siswa dalam belajar dan bagi guru dalam membelajarkan siswa untuk bidang studi atau mata pelajaran tertentu. Berdasarkan pemaparan di atas, buku ajar memiliki fungsi sebagai acuan wajib dalam pembelajaran mata pelajaran tertentu. Urgensi buku ajar dalam pembelajaran telah dipaparkan oleh Al-Gali dan Abdullah (2012:10) adalah menjadikan proses pembelajaran dapat berjalan dan menghubungkan guru dan siswa sehingga menghasilkan tujuan yang diinginkan. Dengan demikian, diperlukan adanya buku ajar bahasa Arab yang berkualitas agar dapat memenuhi kebutuhan tersebut.

Kriteria isi buku ajar pelajaran yang layak digunakan oleh satuan pendidikan telah ditetapkan oleh BSNP sebagaimana disebutkan dalam Peraturan Menteri Pendidikan dan Kebudayaan Republik Indonesia Nomor 8 Tahun 2016 tentang buku yang digunakan dalam satuan pendidikan Pasal 3 ayat 5 bahwa bagian isi buku pada buku ajar dalam pelajaran wajib memenuhi aspek materi, aspek kebahasaan, aspek penyajian materi, dan aspek kegrafikaan.

Buku ajar mengandung materi ajar yang dapat membantu guru dalam melaksanakan kegiatan belajar mengajar. Materi dalam buku ajar merupakan materi tertulis. Materi dalam buku ajar memuat substansi pelajaran yang disusun secara sistematis, menampilkan sosok utuh dari kompetensi yang akan dikuasai oleh siswa dalam kegiatan pembelajaran berdasarkan kurikulum yang sedang berlaku agar siswa mampu menguasai semua kompetensi secara utuh dan terpadu.

Al-Qasimy (dalam Asrofi dan Pransiska, 2016:45) menyebutkan bahwa buku ajar bahasa Arab ada beberapa komponen materi yang harus dipenuhi yaitu: 1) Bacaan-bacaan (almuțāla'ah) tentang hal-hal yang berkaitan dengan kehidupan siswa. agar lebih komunikatif bacaan itu hendaknya berbentuk tanya-jawab; 2) Kaidah-kaidah bahasa Arab (qawä'id al-lugah al-'Arabiyyah) dengan menggunakan rumusan bahasa siswa yang bersangkutan, hendaknya dilakukan guru sesudah bacaan dan sebelum mengawali latihan; 3) Beberapa latihan (altadribat) lisan maupun tertulis yang dikerjakan siswa dengan bimbingan guru; 4) Tahapantahapan penyajian bahan ajar harus diperhatikan agar tidak merugikan efektivitas belajar mengajar bahasa. 5) Kamus singkat yaitu kamus yang berisi kata-kata baru dalam buku tersebut yang dirasa sulit oleh siswa 6) Materi Pendukung yang meliputi perkamusan, bukubuku latihan, dan buku pedoman bagi guru. 
Kemudian, di samping komponen materi ajar, kualitas materi ajar juga perlu diperhatikan dalam sebuah buku ajar. Materi ajar tidak hanya harus sesuai dengan kurikulum, tetapi juga berkualitas. Dalam hal ini, William Francis Mackey dalam bukunya "Language Teaching Analysis" memaparkan aspek-aspek dalam melihat kualitas materi ajar bahasa dalam sebuah buku ajar yaitu aspek seleksi, aspek gradasi, aspek presentasi, dan aspek repetisi.

Buku ajar bahasa Arab kelas VI terbitan karya Toha Putra dipilih karena dalam buku ini ditemukan hilangnya harakat dalam huruf Arab. Kosakata yang dipakai kurang relevan dengan kehidupan sehari-hari siswa, tidak adanya kamus kecil di setiap bab, penjelasan struktur kebahasaan yang lebih menekankan contoh tetapi kurang penjelasan struktur kebahasaan yang digunakan.

Berdasarkan masalah tersebut, peneliti bermaksud menganalisis kualitas buku ajar kelas VI terbitan karya Toha Putra. Apakah sudah sesuai dengan standar buku ajar yang layak digunakan sebagaimana telah ditetapkan oleh Badan Standar Nasional Pendidikan (BSNP) dan apakah buku tersebut menyajikan materi ajar yang berkualitas jika dilihat dari prinsip seleksi, gradasi, presentasi, repetisi.

\section{METODE}

Pendekatan penelitian yang digunakan dalam penelitian ini adalah pendekatan kualitatif. Adapun metode penelitian yang digunakan dalam penelitian ini adalah dengan menggambarkan menggunakan penjabaran secara deskriptif hasil penelitian tetapi tidak digunakan untuk membuat kesimpulan yang lebih luas. Tujuan penggunaan metode ini adalah untuk mendeskripsikan kesesuaian buku dengan standar nasional dilihat dari aspek penyajian, isi, bahasa, dan grafika. Serta kualitas materi ajar yang dilihat dari aspek seleksi, gradasi, presentasi, repetisi.

Sumber data dalam penelitian ini ada dua yaitu sumber data primer dan sumber data sekunder. Dalam penelitian ini sumber data primernya, yaitu buku ajar bahasa Arab kelas VI Madrasah Ibtidaiah terbitan karya Toha Putra, dan dokumen yang berkaitan dengan kesesuaian buku dengan standar nasional dilihat dari aspek penyajian, isi, bahasa, dan grafika serta, kualitas materi ajar yang dilihat dari aspek seleksi, gradasi, presentasi, repetisi. Dalam penelitian ini, sumber data sekundernya yaitu berbagai buku dan jurnal yang relevan dengan penelitian ini. 
Instrumen dalam penelitian ini adalah peneliti sendiri. Peneliti mengumpulkan data yang dibutuhkan, diperlukan tahapan teknis dalam pengumpulan data. Teknik pengumpulan data yang peneliti gunakan dalam penelitian ini yaitu studi pustaka dan studi dokumentasi.

Studi pustaka peneliti lakukan dengan cara kajian tentang kesesuaian buku dengan standar nasional dilihat dari aspek penyajian, isi, bahasa, dan grafika serta, kualitas materi ajar yang dilihat dari aspek seleksi, gradasi, presentasi, repetisi. Dalam hal ini, yaitu buku ajar bahasa Arab kelas VI terbitan karya Toha Putra dan sumber-sumber lain yang membahas buku ajar, kurikulum dan kualitas materi ajar.

Studi dokumentasi dalam penelitian ini, peneliti lakukan dengan cara mengumpulkan dokumen-dokumen resmi negara tentang kurikulum 2013 dari kemendikbud serta kurikulum 2013 di madrasah ibtidaiah dari kemenag. Setelah dikumpulkan, peneliti melakukan analisis buku ajar bahasa Arab kelas VI Madrasah Ibtidaiah terbitan karya Toha Putra dan kesesuaiannya dengan standar nasional dilihat dari aspek penyajian, isi, bahasa, dan grafika serta, kualitas materi ajar dalam buku tersebut dilihat dari aspek seleksi, gradasi, presentasi, repetisi.

\section{HASIL DAN PEMBAHASAN}

Pembelajaran merupakan suatu proses untuk mencapai tujuan pendidikan yaitu menjadikan manusia yang lebih baik. Sunhaji (2014:32) mengatakan "Proses pembelajaran adalah suatu usaha untuk membuat siswa belajar, sehingga situasi tersebut merupakan peristiwa belajar (event of learning) yaitu usaha untuk terjadinya perubahan tingkah laku dari siswa. tingkah laku dapat terjadi karena adanya interaksi antara siswa dengan lingkungannya”.

Pembelajaran memerlukan bahan pembelajaran. Bahan pembelajaran merupakan isi kurikulum seperti yang telah dijelaskan oleh Ruhimat, dkk. (2016:152), "Bahan atau materi pembelajaran pada dasarnya adalah isi dari kurikulum, yakni berupa mata pelajaran atau bidang studi dengan topik/subtopik dan rinciannya".

Menurut UU Nomor 20 tahun 2003 tentang Sistem Pendidikan Nasional Pasal 1 Ayat 19, Kurikulum adalah seperangkat rencana dan pengaturan mengenai tujuan, isi, dan bahan pelajaran serta cara yang digunakan sebagai pedoman penyelenggaraan kegiatan pembelajaran untuk mencapai tujuan pendidikan tertentu.

Karena bahan pembelajaran merupakan isi dari kurikulum, maka setiap bahan pembelajaran harus dapat menyajikan bahan ajar sesuai kurikulum yang berlaku untuk setiap mata pelajaran yang disesuaikan dengan siswa sasaran dari bahan pembelajaran tersebut. 
Kurikulum yang berlaku saat ini di Indonesia, merupakan kurikulum 2013. Mulyasa (2013:163) menjelaskan tentang kurikulum 2013 yaitu "Kurikulum yang berbasis kompetensi. Tidak hanya menekankan kepada penguasaan kompetensi siswa, melainkan juga pembentukan karakter. Sesuai dengan kompetensi inti (KI) yang telah ditentukan oleh Kementerian Pendidikan dan Kebudayaan Republik Indonesia (Kemdikbud RI) , KI 1 dan KI 2 berkaitan dengan tujuan pembentukan karakter siswa sedangkan KI 3 dan KI 4 berkaitan dengan penguasaan kompetensi siswa." Oleh karena itu, bahan pembelajaran harus sesuai dengan kurikulum 2013 yang mengandung kompetensi inti yang telah ditentukan oleh (Kemdikbud RI) pada setiap mata pelajaran.

Buku ajar banyak merupakan jenis bahan pembelajaran yang banyak dipakai oleh banyak mata pelajaran di berbagai sekolah dan madrasah. Buku ajar merupakan salah satu cara untuk menerapkan kurikulum. Buku ajar diperlukan untuk menunjang proses pembelajaran. termasuk pembelajaran bahasa Arab yang memerlukan buku ajar bahasa Arab. Materi pada buku ajar bahasa Arab haruslah menyesuaikan dengan karakteristik bahasa Arab.

Buku ajar bahasa Arab diharapkan mampu menunjang pembelajaran bahasa Arab dengan guru di sekolah, serta dapat menunjang pembelajaran di rumah baik dengan bimbingan orang tua ataupun pembelajaran mandiri oleh siswa. Dengan demikian, diperlukan adanya buku ajar bahasa Arab yang berkualitas agar dapat memenuhi kebutuhan tersebut.

Kebutuhan tersebut dapat dipenuhi pembelajaran menggunakan buku yang baik adalah buku ajar yang memenuhi beberapa persyaratan, yaitu : 1) Memenuhi kriteria isi buku ajar yang layak digunakan oleh satuan pendidikan 2) Materi dalam buku teks sesuai dengan kurikulum mata pelajaran di mana buku tersebut diperuntukkan serta merupakan materi yang berkualitas.

Kriteria isi buku teks pelajaran yang layak digunakan oleh satuan pendidikan telah ditetapkan oleh BSNP sebagaimana disebutkan dalam Peraturan Menteri Pendidikan dan Kebudayaan Republik Indonesia Nomor 8 Tahun 2016 tentang buku yang digunakan dalam satuan pendidikan Pasal 3 ayat 5 bahwa bagian isi buku pada Buku Teks Pelajaran wajib memenuhi aspek materi, aspek kebahasaan, aspek penyajian materi, dan aspek kegrafikaan.

Muslich (2010:292-303) menegaskan bahwa indikator dalam melakukan penilaian buku ajar sesuai standar nasional, yaitu :

Dalam hal penilaian kelayakan isi, ada tiga indikator yang harus diperhatikan, yaitu: kesesuaian uraian materi dengan standar kompetensi (sk) dan kompetensi dasar (kd) yang 
terdapat dalam kurikulum mata pelajaran yang bersangkutan, keakuratan materi, dan materi pendukung pembelajaran.

Dalam hal penilaian kelayakan penyajian, ada tiga indikator yang harus diperhatikan, yaitu: teknik penyajian, penyajian pembelajaran, dan kelengkapan penyajian.

Dalam hal penilaian kelayakan bahasa, ada tiga indikator yang harus diperhatikan, yaitu: kesesuaian pemakaian bahasa dengan tingkat perkembangan siswa, pemakaian bahasa yang komunikatif, dan pemakaian bahasa memenuhi syarat ketentuan dan keterpaduan alur berpikir.

Sedangkan dalam hal penilaian kelayakan kegrafikaan, ada tiga indikator yang harus diperhatikan, yaitu: ukuran buku, desain kulit buku, dan desain isi buku.

Kemudian, di samping keempat aspek tersebut, materi ajar juga perlu diperhatikan dalam sebuah buku teks. Materi ajar dalam buku teks tidak hanya harus sesuai dengan kurikulum, tetapi juga berkualitas. William Francis Mackey dalam bukunya "Language Teaching Analysis" memaparkan aspek-aspek dalam melihat kualitas materi ajar bahasa dalam sebuah buku ajar yaitu aspek seleksi, aspek gradasi, aspek presentasi, dan aspek repetisi.

Pada aspek seleksi, Sumardi (1975:42) menjelaskan bahwa Suatu metode mengajar bahasa bagaimanapun harus diadakan seleksi terhadap unsur tata bahasanya, kosakata, tata makna atau semantiknya ataupun gramatikalnya. Dalam seleksi ini, bidang kosakatalah yang mudah diseleksi dan memang seharusnya mengalami seleksi.

Kemudian, pada aspek gradasi Sepriansah (2015:16) mengemukakan “Gradasi yaitu penyusunan materi yang telah diseleksi bisa diajarkan sekaligus. Gradasi yang sistematis akan mengurangi kesulitan dalam mempelajari bahasa Arab yaitu dengan cara menyusun materi bagian-bagian yang berurutan agar tidak terjadi kekacauan".

Nurhadi (1995:365) mengelompokkan materi unit-unit pelajaran dalam dua kategori, yaitu pengelompokan struktural dan pengelompokan semantik. Pengelompokan struktural lebih menekankan pada kompetensi linguistik, sedangkan pengelompokan semantik menekankan pada kemampuan komunikatif atau kompetensi komunikatif.

Kemudian pada aspek presentasi, Pransiska (2018:10) bahwa presentasi terkait dengan bagaimana penyampaian materi agar materi tersebut bisa dipahami oleh peserta didik, jadi apa yang tampak pada halaman-halaman pertama buku teks, itulah presentasi.

Sumardi (dalam Pransiska, 2018:10) menjelaskan prosedur dalam presentasi buku ajar yaitu: 
a. Prosedur diferensial, yaitu prosedur yang berdasarkan atas perbedaan arti antara Bahasa pertama dan Bahasa kedua. Prosedur ini bertujuan menjelaskan sebuah kaidah dengan menerjemahkan penjelasannya dalam bahasa pertama siswa;

b. Prosedur ostentif, yaitu prosedur mengajar bahasa dengan menggunakan objek, tindakan, gerak-gerik tangan dan muka serta perbuatan lainnya, serta dengan menciptakan situasi untuk menjelaskan kepada siswa;

c. Prosedur pictorial, yaitu prosedur mengajar dengan menggunakan gambar; dan

d. Prosedur konteks, yaitu prosedur pengajaran dengan menggunakan konteks yang sifatnya verbal, seperti penggunaan definisi, enumerasi, substitusi, metaphor, oposisi dan konteks ganda.

Kemudian pada aspek repetisi, Pransiska (2018:11) menjelaskan "Repetisi adalah pengulangan dalam konteks ini diartikan sebagai penguatan, pelatihan, atau penajaman. Penajaman adalah langkah yang ditempuh oleh penulis buku teks agar materi yang disajikan itu dapat dicerna dan diinternalisasikan oleh siswa menjadi kompetensi berbahasa yang siap dipakai".

Repetisi dapat dilakukan dengan latihan produktif dan latihan reseptif. Pransiska (2018:11) menyebutkan, "latihan reseptif mencakup keterampilan menyimak dan membaca, perlu dikemukakan bahwa pelatihan untuk mempertinggi bahasa tidak semuanya tersampaikan dalam pelatihan mufradat. Dalam hal-hal tertentu perlu adanya usaha-usaha kreatif guru bahasa dalam mengajar secara manual. Pelatihan membaca dapat dilakukan dengan; Menjawab pertanyaan; Membuat catatan; Membuat ikhtisar; dan Membuat catatan tunggal bacaan. Latihan produktif mencakup dua keterampilan pokok, yaitu keterampilan berbicara dan keterampilan menulis. Dalam praktiknya dua aspek ini dapat diintegrasikan dengan keterampilan membaca dan menyimak. beberapa cara yang dapat ditempuh untuk meningkatkan keterampilan produktif tulis antara lain berlatih menyusun atau membuat ringkasan, menyusun tulisan, narasi, membuat lukisan, menulis bebas atau menerjemahkan".

Menurut Nurhadi (1995:389) latihan keterampilan berbicara dapat dilakukan dengan cara; Praktik dialog atau bercakap-cakap dalam bahasa yang sedang dipelajari; Latihan pola; Berlatih menirukan secara langsung; Latihan lihat dan ucapkan; dan Mengarang lisan.

Buku bahasa Arab kelas VI Madrasah Ibtidaiah terbitan karya Toha Putra belum memenuhi beberapa indikator dari setiap aspek penilaian standar buku ajar. Jika dilihat dari kelayakan isi, materi yang disajikan akurat dengan materi pendukung yang tepat meskipun 
demikian belum sesuai dengan KI dan KD yang terdapat pada kurikulum. Jika dilihat dari aspek kelayakan penyajian baik dari segi teknik penyajian, penyajian pembelajaran, dan kelengkapan penyajian belum sesuai dengan standar. Jika dilihat dari aspek kelayakan bahasa, buku ini sesuai dengan standar baik dari aspek kesesuaian pemakaian bahasa dengan tingkat perkembangan siswa, pemakaian bahasa yang komunikatif, pemakaian bahasa memenuhi syarat keruntutan dan keterpaduan alur berpikir. Jika dilihat dari aspek kelayakan grafika dari aspek ukuran buku dan desain isi buku, buku ini telah sesuai dengan standar, namun terdapat ketidaksesuaian dari desain kaver depan buku.

Selain daripada penilaian buku ajar berdasarkan standar buku ajar yang telah ditentukan BSNP di atas, buku ajar kurikulum 2013 memiliki kriteria tersendiri yang menjadi ciri khas buku ajar kurikulum 2013 dari buku ajar kurikulum sebelumnya. Kriteria tersebut yaitu :

1. Dalam kurikulum 2013, buku ditulis mengacu kepada konsep kurikulum (KI, KD, silabus).

2. Dalam mengajar ada dua jenis buku (buku siswa dan buku guru).

3. Buku siswa lebih ditekankan pada activity base bukan merupakan bahan bacaan.

4. Setiap buku memuat model pembelajaran dan project yang akan dilakukan oleh siswa.

5. Buku guru memuat panduan bagi guru dalam mengajarkan materi kepada siswa.

Jika dilihat dari kriteria tersebut, buku ini telah mengacu kepada konsep kurikulum (KI, KD, silabus), walaupun masih banyak adanya ketidaksesuaian, buku ini hanya tersedia satu jenis buku yaitu buku siswa sedangkan buku guru tidak tersedia. Buku siswa lebih ditekankan pada activity base seperti kegiatan-kegiatan yang dapat membantu siswa dalam mencapai empat kemahiran berbahasa. Buku ini tidak memuat model pembelajaran dan project yang akan dilakukan oleh siswa.

Buku ajar mengandung materi ajar yang dapat membantu guru dalam melaksanakan kegiatan belajar mengajar. Materi dalam buku ajar merupakan materi tertulis. Materi dalam buku ajar memuat substansi pelajaran yang disusun secara sistematis, menampilkan sosok utuh dari kompetensi yang akan dikuasai siswa dalam kegiatan pembelajaran berdasarkan kurikulum yang sedang berlaku agar siswa mampu menguasai semua kompetensi secara utuh dan terpadu. 
Berdasarkan komponen materi yang harus dipenuhi dalam buku ajar bahasa Arab buku ini sudah memenuhi seluruh komponen tersebut. Buku ini memuat bacaan-bacaan (almuțala'ah) berbentuk tanya-jawab (dialogis) maupun teks sederhana tentang hal-hal yang berkaitan dengan kehidupan mereka yaitu di sekolah, di rumah maupun di masyarakat.

Buku ini juga memuat kaidah-kaidah bahasa Arab (qawaid al-lughah al-'Arabiyyah). Hanya saja kaidah tadi ditaruh sesudah bacaan-bacaan (al-muțala'ah) berbentuk tanya-jawab (dialogis) dan sebelum mengawali bacaan-bacaan (al-muțala'ah) berbentuk teks sederhana, serta beberapa latihan selanjutnya yang berkaitan dengan kemahiran membaca dan menulis.

Buku ini memuat beberapa latihan (al-tamarin) baik latihan secara lisan maupun tertulis yang mesti dikerjakan oleh siswa dengan bimbingan guru yang bersangkutan.

Tahapan-tahapan penyajian bahan pelajaran pada buku ajar dapat dilihat dari seleksi dan gradasi materi ajar yang akan dibahas peneliti dalam pembahasan kualitas materi pada buku ajar ini.

Buku ini memuat kamus, yang berisi kata-kata yang dirasa sulit oleh siswa atau pembelajar yang diletakkan di halaman terakhir dari buku ajar.

Materi pendukung dalam buku ini, Secara garis besar materi-materi pendukung itu meliputi kamus untuk buku lainnya seperti buku-buku latihan, buku bacaan, dan buku pedoman bagi guru belum tersedia.

Adapun materi ajar bahasa Arab kelas VI berdasarkan kurikulum dalam Peraturan Menteri Agama Republik Indonesia Nomor 000912 Tahun 2013 Tentang Kurikulum Madrasah 2013 Mata Pelajaran Pendidikan Agama Islam dan Bahasa Arab Bab III Standar Isi Pendidikan Agama Islam dan Bahasa Arab di Madrasah yaitu :

1. Mufradat dan bacaan tentang topik : أعمالنا في المدرسة وفي البيت

2. Pengenalan tarkib : fi'il mudari'

3. Mufradat dan bacaan tentang topik : Mم الساعة و في أي ساعة

4. Pengenalan tarkib : fi'il mudari'

5. Mufradat dan bacaan tentang topik : تعليم اللغة العربية

6. Pengenalan tarkib : fi'il amr

7. Mufradat dan bacaan tentang topik الو اجب المنزلي:

8. Pengenalan tarkib : fi'il maḍi

9. Mufradat dan bacaan tentang topik : النزهة

10. Pengenalan tarkib : fi'il maḍi 
Materi dalam buku ini memuat seluruh materi tersebut pada bab 1 yaitu, memuat

tema tentang أعمال يومية (في البيت و في المدينة) pekerjaan di rumah dan kota. Padahal seharusnya tema yang diangkat yaitu أعمالنا في المدرسة وفي البيت pekerjaan kami di rumah dan di sekolah.

Kemudian, di bawah ini merupakan hasil dan pembahasan kualitas materi ajar bahasa Arab kelas VI Madrasah Ibtidaiah terbitan karya Toha Putra yang dinilai dari empat aspek yaitu, seleksi, gradasi, presentasi, dan repetisi.

Pada aspek seleksi, peneliti telah menyeleksi kosakata yang sesuai dengan kriteria dasar dalam menyeleksi kosakata. Pada bab satu peneliti menyeleksi 53 kosakata, pada bab dua peneliti menyeleksi 45 kosakata, pada bab tiga peneliti telah menyeleksi 39 kosakata. Pada bab empat peneliti telah menyeleksi 42 kosakata, pada bab lima peneliti telah menyeleksi 35 kosakata.

Pada aspek gradasi, buku telah memenuhi aspek gradasi baik pada segi pengelompokan dan pengurutan. Pada aspek presentasi, buku telah memenuhi aspek presentasi dengan memenuhi empat macam model presentasi pada buku ajar bahasa yaitu prosedur diferensial, prosedur ostentif, prosedur pictorial, dan prosedur kontekstual. Pada aspek repetisi, peneliti menemukan bahwa untuk latihan repetisi menyimak dan berbicara penulis sajikan dalam bentuk percakapan. Pada buku ini latihan mendengarkan dengan menggunakan percakapan pada buku ini dilakukan dengan menyebutkan kalimat untuk diperagakan. Sedangkan, pada latihan berbicara dalam buku ini, dengan berlatih menirukan secara langsung percakapan yang ada. Pada latihan membaca, dalam buku ini dilakukan dengan menjawab pertanyaan sesuai dengan bacaan. pada latihan menulis dalam buku ini dilakukan dengan cara menyusun kalimat yang benar sesuai pada gambar.

\section{SIMPULAN}

Buku Ajar Bahasa Arab kelas VI Madrasah Ibtidaiah terbitan karya Toha Putra pada beberapa aspek sesuai dan ada yang tidak sesuai. Aspek yang sesuai dengan standar buku ajar BSNP yaitu pada aspek kelayakan bahasa, aspek yang tidak sesuai dengan standar buku ajar BSNP yaitu pada aspek kelayakan penyajian. Sedangkan, ada beberapa indikator yang tidak terpenuhi pada dua aspek lainnya yaitu indikator kesesuaian uraian materi dengan Kompetensi Inti (KI) dan Kompetensi Dasar (KD) yang terdapat dalam kurikulum mata pelajaran yang bersangkutan pada aspek kelayakan isi, indikator desain kulit buku pada aspek kelayakan grafika. 
Kualitas materi dalam Buku Ajar Bahasa Arab kelas VI Madrasah Ibtidaiah terbitan karya Toha Putra pada aspek seleksi, gradasi, dan presentasi baik namun pada aspek repetisi cukup baik.

\section{DAFTAR PUSTAKA}

Al-Gali, A. \& Abdullah, A.H. (2012). Menyusun Buku Ajar Bahasa Arab. Padang: Akademia

Menteri Agama Republik Indonesia. (2013). Peraturan Menteri Agama Republik Indonesia Nomor 000912 Tahun 2013 Tentang Kurikulum Madrasah 2013 Mata Pelajaran Pendidikan Agama Islam dan Bahasa Arab. Jakarta: Kemenag.

Menteri Pendidikan dan Kebudayaan Republik Indonesia. (2016). Peraturan Menteri Pendidikan dan Kebudayaan Republik Indonesia Nomor 8 Tahun 2016 Tentang Buku Yang Digunakan Dalam Satuan Pendidikan. Jakarta: Mendikbud.

Muslich, M. (2010). Text Book Writing : Dasar-Dasar Pemahaman, Penulisan, dan Pemakaian Buku Teks. Sleman: Ar-Ruzz Media.

Nurhadi. (1995). Tata Bahasa Pendidikan (Landasan Penyusunan Buku Pelajaran Bahasa. Semarang: IKIP Semarang Press.

Permata. Asrofi, S. dan Pransiska, T. (2016). Penulisan Buku Teks Bahasa Arab : Konsep, Prinsip, Problematika dan Proyeksi. Yogyakarta: Ombak.

Pransiska, T. (2018). Buku Teks Al-Lughah Al-'Arabiyah Al-Mu'āshirah Bagi Penutur Non Arab: Desain, Kontruksi Dan Implementasi. Al-Fikra: Jurnal Ilmiah Keislaman, 17(1) 1-20. http://dx.doi.org/10.24014/af.v17i1.5123.

Ruhimat, T. Dkk. (2016). Kurikulum dan Pembelajaran. Jakarta : Rajawali Press.

Sepriansah, E. (2015). Analisis Buku Teks Bahasa Arab Madrasah Ibtidaiyah Kelas V Karya A. Syaekhudin, Halid Al-Kaf, dan Jalal Suyuti (Ditinjau dari Materi Ajar). Skripsi. Fakultas Ilmu Tarbiyah dan Keguruan, Universitas Islam Negeri Sunan Kalijaga, Yogyakarta.

Sitepu (2015). Penulisan Buku Teks Pelajaran. Bandung: PT Remaja Rosdakarya.

Sumardi, M. (1975). Pengajaran Bahasa Asing, Sebuah Tinjauan dari Segi Metodologi. Jakarta: PT Bulan Bintang.

Sunhaji, S. (2014). Konsep Manajemen Kelas dan Implikasinya Dalam Pembelajaran. Jurnal Kependidikan, 2(2), 30-46. https://doi.org/https://doi.org/10.24090/jk.v2i2.551. 
ALSUNIYAT: Jurnal Penelitian Bahasa, Sastra, dan Budaya Arab

Wakil Menteri Pendidikan dan Kebudayaan R.I Bidang Pendidikan. (2014). Paparan Wakil Menteri Pendidikan dan Kebudayaan R.I Bidang Pendidikan Konsep dan Implementasi Kurikulum 2013. Jakarta: Mendikbud. 